\title{
The Influence of Poultry Manure Application and Plant Density on the Growth and Yield of Egusi Melon (Colocynthis citrullus) on the Nsukka Plains of South Eastern Nigeria
}

\author{
P. E. Oghonna and I. U. Obi \\ Department of (rop) Science \\ University of Nigeria. Nsukka.
}

\begin{abstract}
A lwo year study: 1995 and 1996. was underiaken to assess the effects of poultry mamure, plamt density and their interaction on the yield and yield componchts of "egusi" melon (Colocynthis citrullus) under Nsukka ecological condrions of south - eastern Nigeria. It was observed lhat fruit prodiction ha', average fruit weight. 1000 - seed we'ight and seed yield hat increased with increase poultry manure applicalion giving seed yield increase of $51 \%$ and $+1 \%$ for 5 and Iot ha' rates respectively over the 0 that rate. It was also observed that higher plant density gare higher frwit and seed yields compared with low plant density. Seed yield weas increased by $31 \%$ and $39 \%$ in the 10.000 and t0.000 plants ha' densitic's compared with the fftt plamts ha' in 1995 and similarly. by $+1 \%$ ond $60 \%$ in 1906. Iligh plant density and increasd poultry mantre application also enhamed

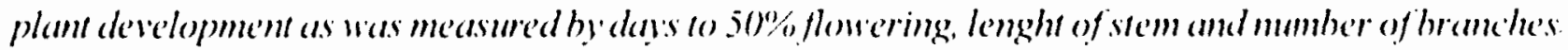

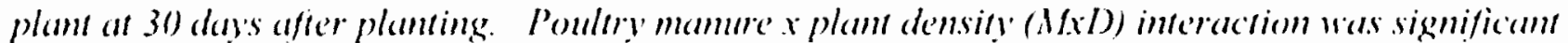

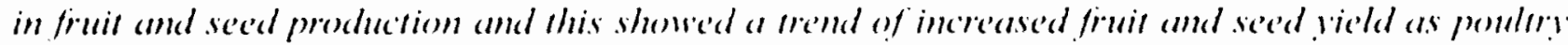
manure use w'as increased with increased plant density rates.
\end{abstract}

Key words." "Igusi" melon, poultry manure. plant density.

\section{INTRODUCTION}

The "egusi" melon (Colocynthis cirrullus) is a member of the cucurbitaceac family. It is a native of Africa where it has been in cultivation for many centuries (Cobley, 1957). The "ligusi" melon seed like soyabean (cilycine" max) is rich in oil $(53.1 \%)$ and protein $(33.8 \%)$ (Okigbo. 1975). In Nigeria, the seeds are prepared into different types of condiments used especialy in soup making. The seed after shelling, can be fermented to prepare "Ogiri" (lgbo) which is a highly proteinous condiment for making soup. The peeled seeds are also ground and used in thickening and enriching soup and stew. The seed oil is commonly. extracted and used for cooking.

In spite of the enormous uses and nutritional qualities of this crop, there is a dearth of information on its agronomy. To achieve increased production of this crop, necessary cultural practices have to be evolved and adopted. Plant density is one of the factors that influence yield and yield components. Evidence is replete in literatures. that increased plant density increased yicld per umit area of land for a number of crops (Squire. 1990. Ofori and Stem. 1987). There is also the need to evaluate the eflect of poultry manure on this crop to evolve optimum rates for use by the local "egusi' farmers under Nsukka ecological conditions. Comtinual depletion of soil fertility through erosion and keaching underscores the need to investigate means of sustaining the soil. Poultry mamure is known to supply many plant nutrients to the soil as well as improving the soil structural conditions. Ogunremi (1978) has shown that fruit and seed yicld ha of egusi melon were signilicantly increased by applying nitrogen (N) up to $48 \mathrm{~kg} \mathrm{~N} \mathrm{hat} \mathrm{beyond} \mathrm{which} \mathrm{yield} \mathrm{dropped}$ signilicantly. Therefore, the objectives of this study are: 
1. to determine the optimum plant density for optimum seed yield of egusi melon.

2. to determine the optimum rate of poultry manure appliction for optimum seed yield, and

3. to asses the plant density $\mathrm{x}$ poultry manure interaction.

\section{Materials and Methods}

The experiments were carried out on April 2, 1995 and April 2, 1996 in the Department of Crop science experimental farm, University of Nigeria, Nsukka (06E 52" N, 07E24' E and altitude $447 \mathrm{~m}$ ). The "egusi' melon cultivar used was purchased from a local 'egusi' farmer from Nsukka, Enugu State, Nigeria.

Poultry manure was of the deep litter system and was in dry condition at purchase. The land was ploughed and harrowed and later prepared manually into beds.

\section{Experiments}

The experiment consisted of three levels of poultry manure $\left(0,5\right.$ and $\left.10 \mathrm{tha}^{-1}\right)$ and three plant densities of $40,000,10,000$ and 4444 plants $\mathrm{ha}^{-1}$ at their respective spacings of $0.5 \mathrm{~m} \times 0.5 \mathrm{~m}$, $1.0 \mathrm{~m} \times 1.0 \mathrm{~m}$ and $1.5 \mathrm{~m} \times 1.5 \mathrm{~m}$. These were laid out as a $3 \times 3$ factorial experiment in randomised complete block design (RCBD) of four blocks. Each block was divided into nine plots each measuring $6 \mathrm{~m} \times 3 \mathrm{~m}$ and each plot was separated from the adjourning plot by a space of one metre. The seeds were hand sown at the rate of one seed per hole on the flat.

Two weedings were carried out throughout the duration of the crop in the field. The first was done manually with hoe three weeks after planting and the second was done by hand pulling at the fifth week after planting since hoe weeding at that stage would damage the vines that had extensively established.

Harvesting was done when the vines had all senesced. The fruits were gathered according to the treatments, cut open with matchet, heaped together and then covered with dry grasses to enhance fermentation of the mesocorp tissue for easy extraction of the seeds. After fermentation. the seeds were extracted and were washed with copious water. The cleaned seeds were collected and sun-dried and weighed.

\section{Experiment}

The 1996 experiment unlike the 1995 experiment was on effect of plant density only and a rate of poultry manure at $5 t$ ha $\mathrm{t}^{-1}$ was used on the three plant density treatments. The remnant of the seed lot for the 1995 experiment still gave $95 \%$ germination and was used in the 1996 planting. The experiment was laid out in a RCBD of four blocks, each divided into three plots.

Data collected in both 1995 and 1996 experiments were days to $50 \%$ seedling emergence, days to $50 \%$ flowering. length of stem and number or branches per plant at 30 days after planting (DAP), number of fruits ha' ${ }^{-1}$. fruit yield hat ${ }^{-1}(\mathrm{~kg})$, average fruit weight $(\mathrm{kg}), 1000$ seed weight $(\mathrm{g})$ and seed yield ha. $(\mathrm{kg})$.

\section{Weather Data}

Concomitant obervations included; the rainfall, relative humidity and temperalure data at Nsukka during the 1995 and 1996 planting seasons which were collected from the Faculty of agriculture meteorological station (NO. $0607.52^{\text {B }}$ ) some 400 metres from the experimental site.

\section{Statistical Analysis}

The analyses were done according to the procedures outlined by Steel and Torrie (1980) and Obi (1995) for factorial experiments. Separation of treatment means for statistical significance was by the F-LSD procedures. (Obi. 1986).

\section{RESULTS}

\section{Weather Information}

Considering the periods of these experiments, $A$ pril to July, 1995 and 1996, higher amount of rainfall was recorded in 1995 than in 1996 (Table 1). The rain, however, was better distributed in the months of $A$ pril and May 1996. 


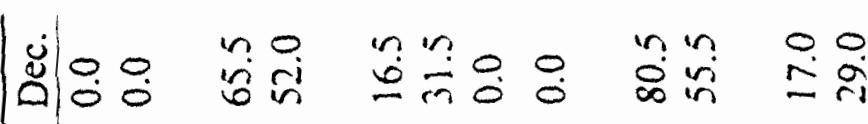

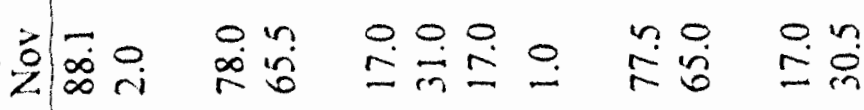

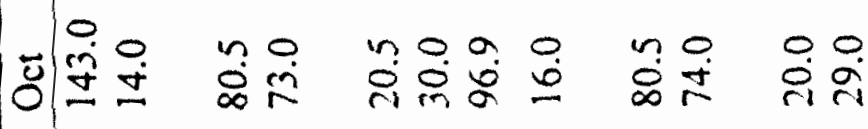

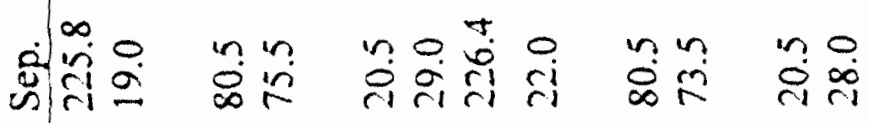

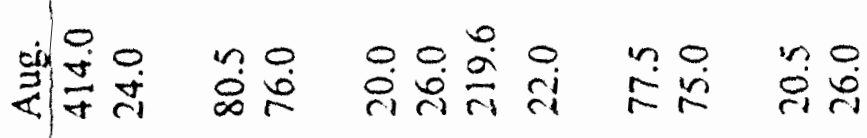

旁苟

트

E⿱

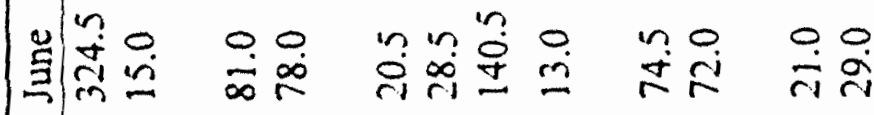

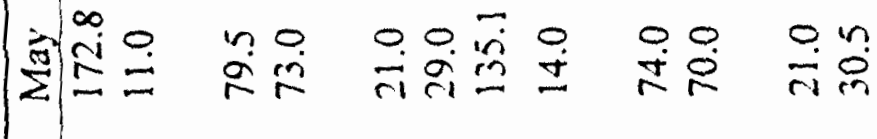
돌

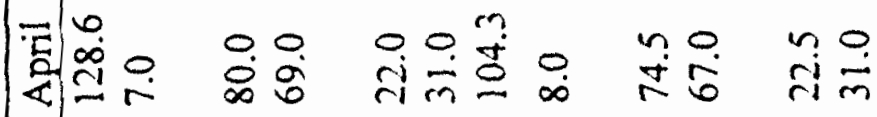
尊芦咅

范

ล

है

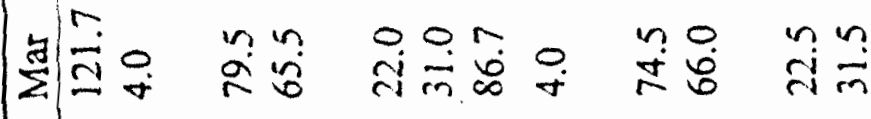

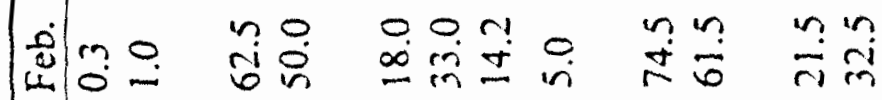

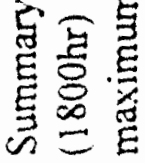

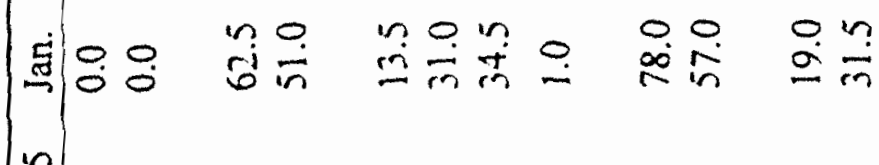

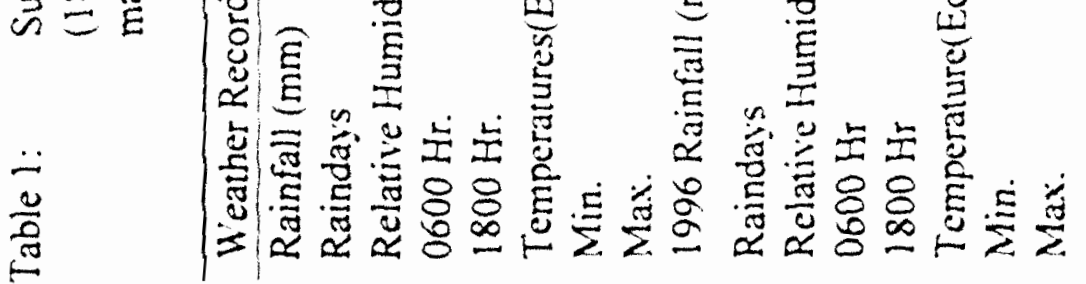


Table 2: Mean effects of poultry manure and plant density and their interaction on the growth and development attributes of the crop.

\begin{tabular}{|c|c|c|c|c|c|}
\hline & \multirow{2}{*}{$\begin{array}{l}\text { Poultry Manure } \\
\text { Rates (Kg ha }\end{array}$} & \multicolumn{4}{|c|}{$\begin{array}{l}\text { Plant Densities } \\
\left.\text { (Plants ha }{ }^{-1}\right)\end{array}$} \\
\hline & & 4,444 & 10,000 & 40,000 & Mean \\
\hline Days to $50 \%$ & 0 & 10.50 & 9.00 & 10.00 & 9.83 \\
\hline Secdling & 5 & 10.75 & 8.75 & 10.00 & 9.83 \\
\hline \multirow[t]{2}{*}{ limergence } & 10 & 11.00 & 10.25 & 10.00 & 10.42 \\
\hline & Mean & 10.00 & 9.33 & 10.75 & 10.03 \\
\hline \multicolumn{6}{|c|}{$F-\operatorname{LSD}(P=0.05)$ for comparing plant density means $=0.83$} \\
\hline Days to $50 \%$ & 0 & 38.75 & 36.25 & 36.75 & 37.25 \\
\hline \multirow[t]{3}{*}{ Flowering } & 5 & 40.00 & 36.50 & 37.25 & 37.92 \\
\hline & 10 & 40.25 & 35.50 & 37.25 & 37.67 \\
\hline & Mean & 39.67 & 36.08 & 37.08 & 37.61 \\
\hline$\because-\operatorname{LSS})(P=0$ & 5) for comparing & lant den & $=1.85$ & & \\
\hline
\end{tabular}

$\begin{array}{llllll}\text { Length of } & 0 & 91.31 & 119.24 & 139.75 & 116.77 \\ \text { Stcm }(\mathrm{cm}) \text { at } & 5 & 139.13 & 168.43 & 176.56 & 161.37 \\ 30 \mathrm{DAP} & 10 & 116.00 & 163.69 & 173.90 & 151.20 \\ & \text { Mean } & 115.48 & 150.45 & 163.40 & 143.11\end{array}$

F-L.SD(P=0.05) for comparing plant density means $=24.06$

$P-L . S D(P=0.05)$ for comparing poultry manure rate means $=24.06$

$P-L . S D(P=0.05)$ for comparing $M X D$ interaction means $=41.67$

$\begin{array}{lcclll}\text { Number of } & 0 & 3.75 & 4.50 & 4.00 & 4.08 \\ \text { branches/ } & 5 & 5.75 & 6.00 & 4.50 & 5.42 \\ \text { plant at 30 } & 10 & 4.00 & 6.50 & 5.75 & 5.42 \\ \text { DAP } & & 4.50 & 5.67 & 4.75 & 4.97\end{array}$

$P-I . S D(P=0.05)$ for comparing plant density means $=0.82$

$\mathrm{F}-\mathrm{L} . \mathrm{SD}(\mathrm{P}=0.05)$ for comparing poultry manure rate means $=0.82$

but at the later months of June and July clistribution was better in 1995. The atmosplere was also more humid in 1995 them in 1996. and cemperature variation between the years was minimal.

\section{Experiments}

\section{Growth and Development Parameters}

Poultry manure had no statistically significant effects on days to $50 \%$ seedling emergence while the effects of planting density was not consistent (Table 2). Number of days to $50 \%$ flowering was not significantly allected by poultry manure application. Planting at low density significantly increased number of days to $50 \%$ flowering. The poultry manure $x$ plant density interaction had no significant effect on this attribute. It was also observed that the application of $5 \mathrm{t}$ ha. rate of poultry manure significantly increased stem length compare with when manure was not applied. Further increase in the application of poultry manure to $10 \mathrm{th} \mathrm{h}^{-1}$ had no further significant effect. Increased plant density resulted to significant increase in stem length. hence planting at 40.000 plants ha resulted in the production of stem length that was higher than what was obtained from 10.000 plants ha. The lowest value was obtained from 4.444 plants hat treatment. A significant poultry manure $x$ plant density interaction indicated increasing stem length as poultry manure 
application and plant density were increased: however longest stem length was obtained when planting was done at 40,000 plants ha ${ }^{-1}$ with $5 t$ ha' rate of poultry manure. The result also showed that the application of $5 t$ and $10 t$ hat rates of poultry manure gave the sume number of branches per plant. the values of which were signifieantly higher than the value obtained where no poultry manure was applied. Similarly planting at the highest density of 40,000 plants hat ${ }^{-1}$ and the lowest of 4.444 plants ha ${ }^{1}$ produced the same number of branches per plant which were significantly lower than what was produced when planted at 10.000 plants hat. manure gave the highest number of fruits ha' and was significantly higher than the values obtained when 0 or $101 \mathrm{ha}^{-1}$ rates was applied. Number of fruits ha' increased significanlly with increased plant density henee highest value was obtained from the highest plant density of $40,000()$ plants hat while the least was obtained from the 4.444 plants ha density. Significant poultry manure $x$ plant density interaction effect showed that the application of $5 t$ hat rate of manure produced the highest number of fruits at the higher plant density levels. while at the lower planty density, increased application of manure resulted to lower number of fruits hat. The

Table 3: Mean effects of poultry manure and plant density and their interaction on the yicld attributes of the crop.

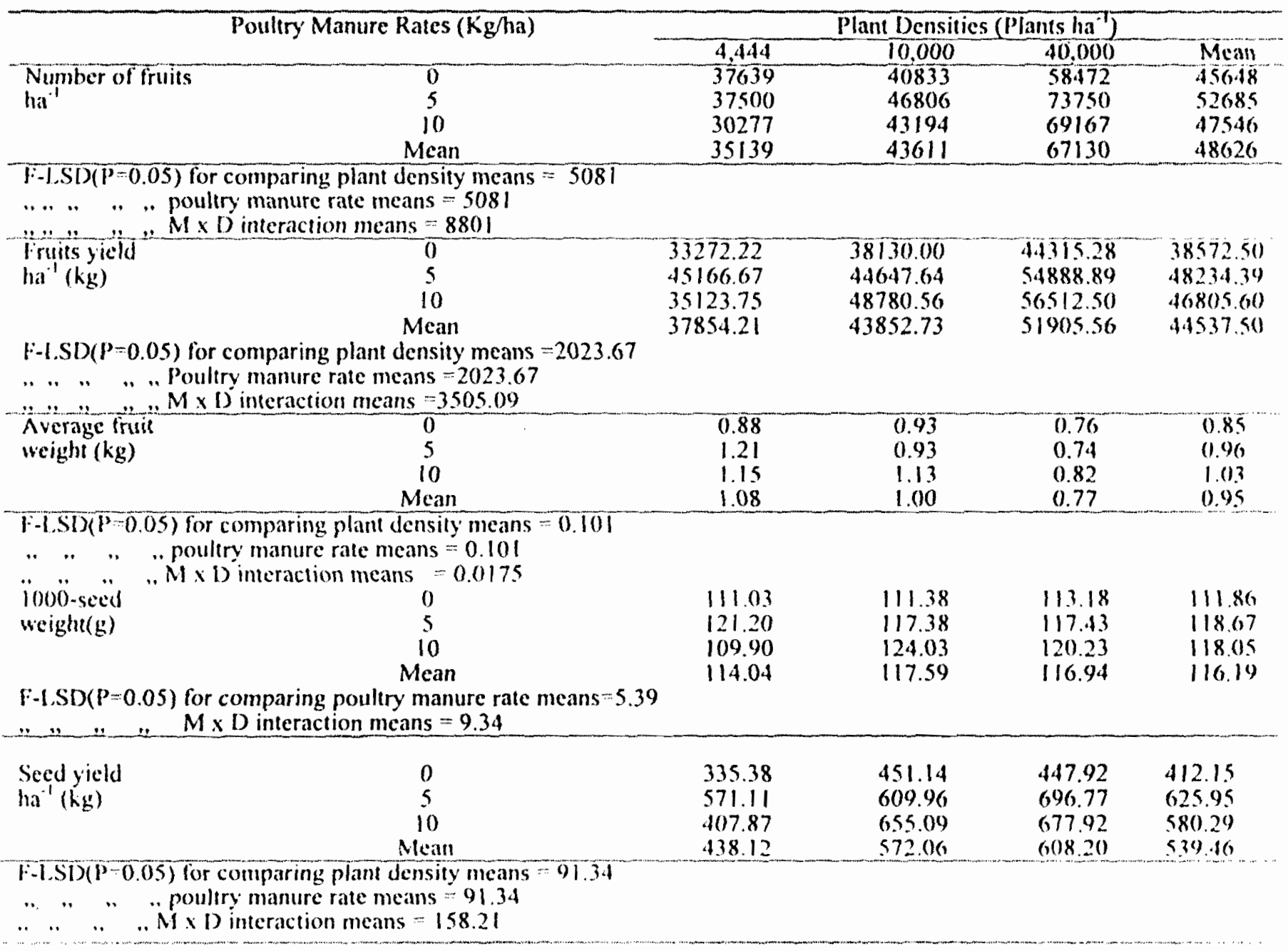

\section{Yicld and Yield Parameters}

Application of $5 \mathrm{t} \mathrm{ha} \mathrm{a}^{-1}$ rate of poultry highest number of fruits hat was produced when 5 t hat manure rate was used on 40.000 plants 
ha ${ }^{-1}$. Further increase of manure application to $10 t \mathrm{ta}^{-1}$ decreased number of fruits ha ${ }^{-1}$ in all plant denstiy levels.

Fruit yicld hat was significantly increased with increasing poultry manure rates. Increased plant density also increased fruit yicld of 4,444 plants ha ${ }^{-1}$ highest average fruit weight was produced from $5 t$ ha. manure rate which was also the highest value obtained among all the combinations.

Application of 5 hat of poultry manure significantly increased 1.000 - seed weight

Table 4: Effect of plant density on the attributes of egusi melon growth, development and yield in 1996 Growth, development and yield measurements.

\begin{tabular}{|c|c|c|c|c|c|c|c|c|c|}
\hline 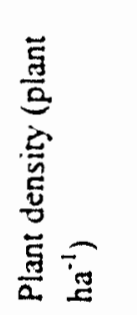 & 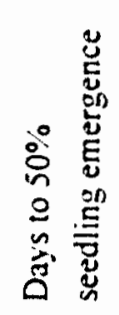 & 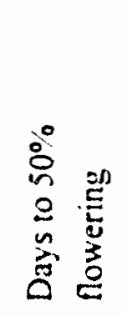 & 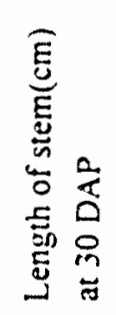 & 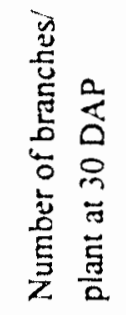 & 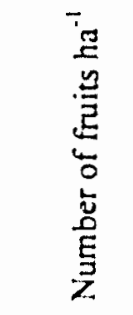 & 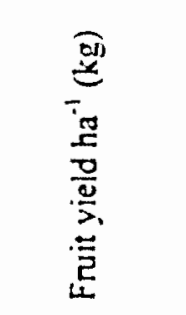 & 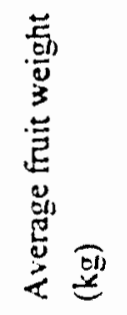 & 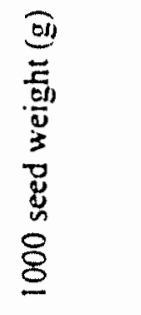 & 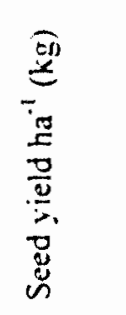 \\
\hline 4.444 & 7.50 & 37.25 & 94.58 & 4.33 & 21944 & 21083.33 & 0.97 & 112.22 & 409.93 \\
\hline 10.000 & 8.00 & 38.50 & 80.92 & 4.67 & 29444 & 29388.89 & 0.96 & 109.99 & 577.64 \\
\hline 40,000 & 7.75 & 36.50 & 61.50 & 3.67 & 40.000 & 31986.11 & 0.81 & 109.99 & 6.54 .64 \\
\hline $\begin{array}{l}f(I . S I) \\
(p \rightarrow 0)(0)\end{array}$ & - & - & 14.02 & - & $\cdot$ & - & - & - & - \\
\hline
\end{tabular}

$h^{\prime \prime}$. There was significant interaction effect of poultry manure and plant density on fruit yield $\mathrm{ha}^{-1}(\mathrm{~kg})$ and this showed a trend of increased fruit yield wih increased plant density and poultry manute rates, hence the highest fruit yield was recorded when planting was made at 40.000 plants hat with 10 tha' rate of poultry manure while the lowest fruit yield was obtained from the lowest plant population with zero rate of poultry manure.

Weight per fruit increased with increasing manure rates al though statistical significance was not established for the value obtained with $5 t$ compared with 10 t per hectare of poultry manure. similarly weight per fruit increased with decreasing planting density while the values for 10,000 and 4.444 plants per hectare did not differ statistically. The significant poultry manure $x$ plant density interaction observed showed a trend of consistent increase in average fruit weight with increased poultry manure rate at the higher plant density levels of 40.000 and 10.000 plants ha' while at the lowest plant population compared with where no manure was applied. However, application of $10 \mathrm{tha}^{-1}$ manure did not produce any further increase in seed weight over where 5 tha' rate was applied. The poultry manure $x$ plant density interaction showed that the combination of 10 tha. rate poultry manure and 10.000 plants ha. gave the highest 1000 seed weight followed by the value obtained from the combination of $5 \mathrm{t} \mathrm{ha} \mathrm{a}^{-1}$ manure rate and 4,444 plants ha'. The least value was obtained when planting was made at 4,444 plants ha ${ }^{-1}$ with 101 hat manure rate.

Seed yicld was always significanly increased by the application of poultry manure. although there was no siginificant difference between the values obtained with the use of $5 t$ and lot ha poultry manure. Similarly. increasing plant population increased secd yeid although values obtained with planting at 40.000$)$ and 10.000 plants ha were statistically similar. The significant poultry manure $x$ plant density interaction observed showed a sequence of increasing seed yield with the applicalion of 
poultry manure and increasing plant density. The highest seed yield, however, was obtained where St hat rate of poultry manure was used at 40.000 plants ha ${ }^{-1}$. and was followed by the combination of $10 t$ ha. rate of manture and 10.000 plants ha.'. The least value was obtained when planted at 4,444 plants ha' with no manure usage.

\section{Experiments}

There were no significant differences in the effects of plants densities on all the attributes measured in 1996 execpt that of length of vine at 30 DAP (lable 4). Average vine length of plants were highest with low plant density, while the values did not differ signilicantly with 40,000 plants ha' compared with the population of 10.000 plants ha ${ }^{-1}$. Although diflerences in fruit vicld values did not attain statistical signilicance. the higher plant populations gave higher yield values of $39.4-52 \%$ for fruit yield ha ${ }^{\prime}$ and 34 . $82 \%$ for fruit number, higher than what were obtained at the lowest plant population. Seed yicld was similarly affected, hence the higher plant populations gave higher yicld values of $41 \%-59.7 \%$ than what was produced at the lowest plant population.

\section{DISCUSSION}

The lack of ellect of poultry manure on seedling emergence showed that soil nutrien may not be a major lactor affecting seed germination. Possibly such other soil factors as moisture. aeration and temperature may have more influence on seed germination. Fakorede (1983) reported that moisture availability was one of the most important factors aflecting the germination of maize. lilowering in crops has also be shown to be influenced by climatic factors such as temperature and relative humidity (Shaw and Thom, 1951). The non-significant effect of poultry manure on this attribute may be attributed to the lact that these climatic factors had an overwhelming influence, thereby masking the elfect of the applied manure.

The increased stem length and number of branches per plant observed in the crop as a result of increased application of poultry maure was made possible by nutrients being released by the poultry manure (Gupla et al.. 1983).

The high fruit and seed yield resulting from mamure application also suggested the positive response of the crop to murients supplied by poultry manure. This secms to suggest that the soil was low in fertility which was in accordance to the report by Tisdale and Nelson. (1975). that crops respond more to nutricme application in a soil with very low nutrient status than soil with high reserve. It was also noted that $5 t \mathrm{ha}^{-1}$ rate of manure caused greater crop growth. fruit and seed yicld than the $10 \mathrm{th} \mathrm{i}^{1}$ ratc. and this may be an indication that adequate quantities of nutrient elements were supplied by the $51 \mathrm{ha}^{-1}$ rate. Ogunremi (1978) recorded a similar decrease in fruit and seed yield when nitrogen (N) was increased above $48 \mathrm{~kg} \mathrm{ha}{ }^{-1}$. The decline in yield observed at the $10 \mathrm{~h} \mathrm{ha}{ }^{-1}$ rate of poultry manure may also be attributed to the accumulation of toxic materials such as copper. In fact lisdale and Nelson (1975) have noled the accumulation of copper in the soil as one of the problems of excessive use of poultry manure.

The contribution of high plant density on carly attainment of $50 \%$ flowering may be attributed to the moisture conserving posture of the high populated plot which was beneficial during that period of the year when moisture was a limiting factor. This also contributed to the production of longer stems and higher number of branches per plant at 30 days after planting.

The significant increase in fruit and seed yicld which resulted from increased plant population was in conformity with the findings of Squire (1990). Ofori and Stern (1987) and Bolton (1971) in other crops. It was however noted that the increase in fruit prodection caused by increased plant density was in the expense of average fruit weight which decreased significantly with increased plant density.

The production of highest fruit and seed yields from the use of $5 t$ ha $^{-1}$ rate of poultry manure at 40.000 plants ha implies that these levels of the treatments were adequate for optimum ligusi melon production in this area. On the other hand. average fruit weight was highest at the lowest plant density with $5 t$ ha' rate of poultry manure. In Egusi melon production. seed yicld rather than fruit size. is of major important. therefore the levels of these 
treatments that supported high seed yield should be recommended.

\section{REFERENCES}

Bolton, A. (1971). Response of maize vars, in Tanzania to different plant populations and fertilizer levels. Expl. Agric: 7: $193-203$

Cobley. S.L. (1957). An Introduction to the Botany of Tropical Crops. Longman, Queen \& Co. 293pp.

Fakorede, M.A B and Opeke, B.O.(1985). Weather factors affecting the response of maize to planting dates in a tropical rain forest location. Expl. Agric: $2: 31$ - 40 .

Gupta, J.P., Aggarwal, R.K. Gupta, (iN and Kaul P. (1983) Eflect of continuous application of farm yard manure and Urea on soil properties and the production of pearl millet in Western Rajasthan. Indian I. Agric: Sc: 53 (1): $53-56$.

Obi. I.U. (1995). Introduction to Factoral Experiments for $A$ gricultural, Biological and Social Sciences Research. Optimal Int'I Pub. Enugu. Nigeria, 47pp.

Obi, I.U. (1986). Statisfical Methods of Detecting Differences Between Treatmentt Means. SNAAP Press Limited, Enugu. Nigeria, $45 \mathrm{pp}$.

Ofori, F. and Stern, W.R. (1987). Relative sowing time and density of component crops in a maize/cowpea Intercrop system. Expl. Agric: $23: 41-52$

Ogunremi. E.A. (1978). Effect of nitrogen on melon (Citrullus Lanatus) at Ibadan. Nigeria. Expl. Agric: 14:357-365.

Okigbo, B.N. (1975). Neglected plants of horticultural and nutritional importance in traditional farming systems of tropical Africa. Acta Hort. 53: $131-150$.

Shaw, R.II. and Thom, H.C.S. (1951) On the phenology of lield corn. the vegetative period II. Silking to maturity. Agrom. I. 43:9-15

Squire, (i.R. (1990). The Physiology of Tropical Cron Producation. $C A B$ International.
U.K., 229pp.

Stecl, R.G.D. and Torric, J.H1. (1980). Principle and Procedures of Statistics (2nd edition). MeCraw - llill Book Company lnc. N.Y. $633 \mathrm{pp}$.

Tisdale, S.A. and Nelson. W.I. (1975). Soil fertility and fertilizers. Macmillan Publ. Co. Inc (3rd ed.) N.Y. $695 \mathrm{pp}$. 